\title{
離岸堤の設計基準の改善策 IMPROVEMENT OF DESIGN CRITERIA OF DETACHED BREAKWATER
}

\author{
宇多高明 1 ・野志保仁 ${ }^{2}$ ・星上幸良 3 \\ Takaaki UDA, Yasuhito NOSHI and Yukiyoshi HOSHIGAMI \\ 1正会員 工博 (財) 上木研究センター常務理事なぎさ総合研究室長兼日本大学客員教授理工学部 \\ 海洋建築工学科（干110-0016 東京都台東区台東1-6-4) \\ 2 正会員 博（工）（有）アイコムネット環境コンサルティング部 \\ （テ135-0064 東京都江東区青海2-7-4-627） \\ 3 正会員 博（工） 国際航業株式会社河川環境部（ ( 183-0057 東京都府中市春日町1-24-1）
}

\begin{abstract}
The improvement of the national criteria on the construction method of the detached breakwater was discussed. Model calculation of beach changes after the construction of detached breakwaters was carried out using the BG model to show the problems to be revised. The Kanesaki coast was taken as an example of the beach changes after the construction of artificial reef, which is an alternate structure for the detached breakwater. Numerical simulations must be used instead of the past qualitative description in the design method of detached breakwaters.
\end{abstract}

Key Words : Criteria, detached breakwater, BG model, artificial reef, Kanesaki coast

\section{1. まえがき}

離岸堤は，現在でこそあまり造られなくはなって きたが，それでも主要な海岸保全施設のひとつであ り，全国の海岸で多数の離岸堤が造られてきている. 離岸堤の設計基準は，海岸保全施設技術研究会編に よる「海岸保全施設の技術上の基準・同解説」（以 下，「基準」と略）1）で詳述されている。「基準」 の3.6節（pp. 3-86〜3-96）には離岸堤の基準が述べ られているし，また3.7節（pp.3-99〜3-106）には 離岸堤に準じてしばしば造られる人工リーフの記述 がある。しかしながら，基準を読むと今から 20 年以 上前の研究に基づく定性的記述が多く, 侵食対策と しての離岸堤の機能を離岸堤背後での堆砂効果とい う狭い視野で捉えており，海浜全体への影響につい ての配慮が不足しているために, 離岸堤の建設によ り周辺海岸が侵食され, そこにまた対策施設が設置 されるという悪循環を防ぐ仕組みがないことが課題 として指摘できる．基準が作られた当時と比べ，現 在では海浜変形予測のレベルが格段に向上したにも かかわらず，それらを積極的に使うとの視点に立っ た記述はほとんどない。こうした状況より, 本研究 では，現況の「基準」の見直しの必要性について, 芹沢ら ${ }^{2)}$ のBGモデル（Bagnold概念に基づく海浜変 形予測モデル）を用いてモデル的に検討するととも に，離岸堤と同様な機能を持って造られる人工リー フによる海浜変形として福岡県鐘崎海岸の実例 ${ }^{3)}$ を 交えて議論する.

\section{2.「基準」の内容}

「基準」では，まず総論の「(3) 技術上の基準の 性能規定」において性能規定について述べており, 施設の設置や設計における説明責任（アカウンタビ リティ）の確保，新技術の活用によるコスト縮減及 び技術基準の国際整合性の観点から，「目的」，

「機能」及び「性能」を定め, 構造物の安全性や目 的達成にかかわる性能を具体的に規定した上で，最 良の照査法を用いて設計するとしている。また， 3.6 節離岸堤の 3.6.1 目的と機能 <処理基準 >では, 離岸堤の目的を次のように示している。「離岸堤は, 海岸背後にある人命, 資産を高潮及び波浪から防護 すること, 若しくは海岸侵食の防止, 軽減及び海浜 の安定化を図ること又はその両方を目的とし, 汀線 の沖側に設置される天端高が海面よりも高い海岸保 全施設である. 離岸堤は, 消波させることにより越 波を減少させる機能, 漂砂を制御することにより汀 線を維持し若しくは回復させる機能のいずれかの機 能又はその両方の機能を有するものとする.」さら にその解説では，波浪制御と漂砂制御機能それぞれ について以下に述べられている。

\section{（1）波浪制御機能}

離岸堤は，直接的には波浪を制御する構造物であ り，間接的に陸側域の漂砂制御や越波対策の役割を 
担う。波高や越波の低減を目的とした離岸堤の機能 を期待する場合には，離岸堤背後に生じる水位上昇 や開口部の存在などにより必ずしも有効な消波効果 を期待できない場合があるので留意する必要がある。 一方, 離岸堤背後に堆砂しトンボロが形成された場 合にはより高い消波効果が期待できる.

\section{（2）漂砂制御機能}

離岸堤は, 波の回折及び消波によって沿岸方向, または岸沖方向の漂砂を制御する効果を持つ. 砕波 帯内に設置される透過型離岸堤の堆砂機構は次のよ うに考えられる.

a）回折波によって離岸堤背後に向から沿岸方向の 流れが生じるとともに, 離岸堤背後の波高が減衰し, 離岸堤を通って沖から岸に向から流れが発生する.

b）砕波や反射波によって浮遊した底質は，この流 れによって岸側に運ばれる。

c）離岸堤背後は, 離岸堤により他の水域と比べ静 穏域となっているため, 浮遊した底質の一部はここ に沈降し, 離岸堤背後の汀線が前進し, 舌状砂州 （トンボロ）が形成される.

なお, 離岸堤背後の循環流の発達によって沿岸流 が分断され強い沿岸流が生じにくくなるため沿岸漂 砂量を小さくでき, 離岸堤設置範囲において侵食を 抑えられる。一方, 消波効果の高い離岸堤の開口幅 を広くとって設置することにより静的に安定的な海 浜を形成することもできる。このように離岸堤は, 供給土砂が減少した海岸では沿岸漂砂量を減少させ る上で有効な対策となる。ただし，離岸堤によって 沿岸漂砂を完全に止めてしまうと離岸堤の下手側で 侵食が発生する可能性があるため, 下手海岸への影 響について十分な検討が必要である.

さらに3.6.4「照査において考慮すべき条件（処 理基準）」のp. 3-90の「(2)流れおよび漂砂」には 次の記述がある。「一連の海岸において, 導流堤や 突堤あるいは防砂突堤等の構造物によって沿岸漂砂 が遮断されたり, 河川等からの供給土砂が減少すれ ば海岸は侵食されることになる。海岸の侵食あるい は堆積現象に最も大きな影響を与える条件は, 土砂 の供給量および対象海岸付近の漂砂の移動特性であ る. 離岸堤の設計に当っては, 上記事項を把握する ために, 供給源の性状, 河川流出土砂量, 流況, 漂 砂の卓越方向, 連続性などについて十分調査寸る必 要がある.」

また, 離岸堤の堆砂効果に関連し, p. 3-94におい てトンボロ面積比と, 堤長/波長, 設置水深/砕波水 深, 堤長/離岸距離の関係が示されているが, 傾向 を読み取りにくく判断材料として使いにくいし，定 性的意味でp. 3-95で述心゙られているように，「設置 水深における波長よりも離岸堤が長い場合に堆砂効 果が高い」, 「砕波水深より浅い設置水深の場合に 堆砂効果が高い場合が多い。」，「開口幅と堤長の 比が 0.5 以上では, 開口部汀線は後退する場合があ る.」との記述があるのみである. 最後に, p. 3-99
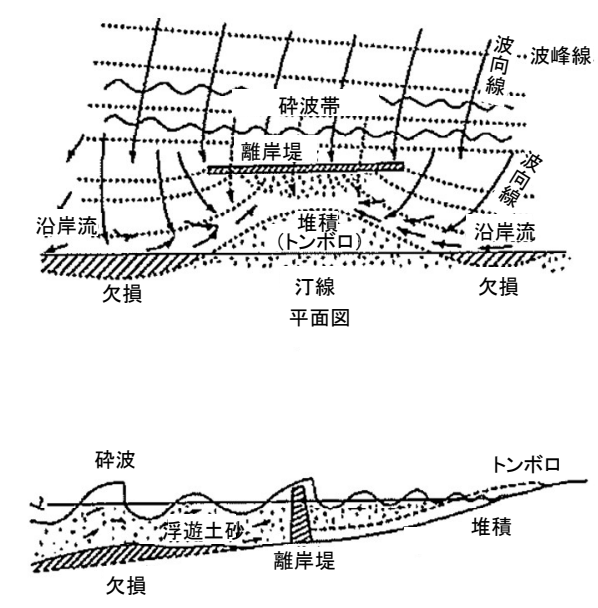

横甽図
図-1 離岸堤の漂砂制御機能の模式図 ${ }^{1)}$

には潜堤・人工リーフの基準があるが，これらの施 設も離岸堤と同様, 消波効果と堆砂効果を持つよう 設計されるので, 離岸堤と似た地形変化が起こる.

\section{3. 基準の疑問点}

2.の漂砂制御機能に関する記述は，豊島が示した 離岸堤の設計基準の考え方をそのまま踏襲している が, 説明文と図-1からは, 離岸堤背後の舌状砂州形 成に要する砂の主要部分は沖合から岸向きに運ばれ たと読める. とくに横断図のみを見て判断すれば上 記判断が正しいと見なされ, 離岸堤を造れば砂浜が ネットで増えるような誤解を招く恐れがある。しか し実際には離岸堤の両脇では著しい侵食が起こる.

図-1の平面図ではそのようにも読めるが，横断図と 平面図の記述内容には矛盾がある。また設計基準に は離岸堤諸元とトンボロ形成などから見た堆砂効果 の関係が述べられているが，そのことが周辺海浜へ 及ぼす影響についての記述はない。また，照査にお いて考慮すべき条件として指摘している, 供給源の 性状, 河川流出土砂量, 流況, 漂砂の卓越方向, 連 続性などより，施設自体の影響評価が優先されるべ き事柄と考えられる.

\section{4. 数値計算による予測のレベル-BG モデルの 適用例}

離岸堤による堆砂効果と周辺海岸の侵食について

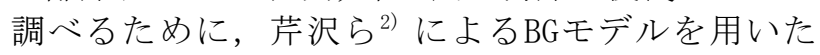
simulationを行った. 計算は単純な条件を設定して 2ケース行った。ケース1では初期地形を勾配 $1 / 30$ の 平行等深線で与えた（図-2 (a) 参照)。平衡勾配は 初期地形と同様 $1 / 30$ とし, 波による地形変化の限界 水深は $\mathrm{h}_{\mathrm{c}}=-6 \mathrm{~m}$, バーム高は $\mathrm{h}_{\mathrm{R}}=3 \mathrm{~m}$ とし, この海浜に 
(a) 初期地形

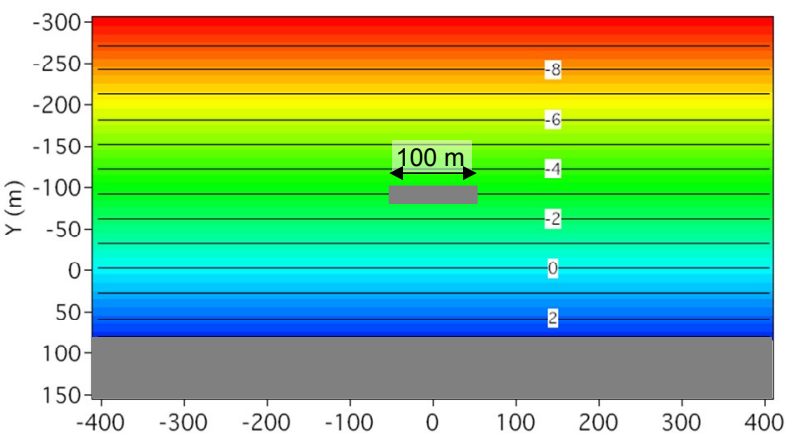

(b) $3 \times 10^{4}$ step後

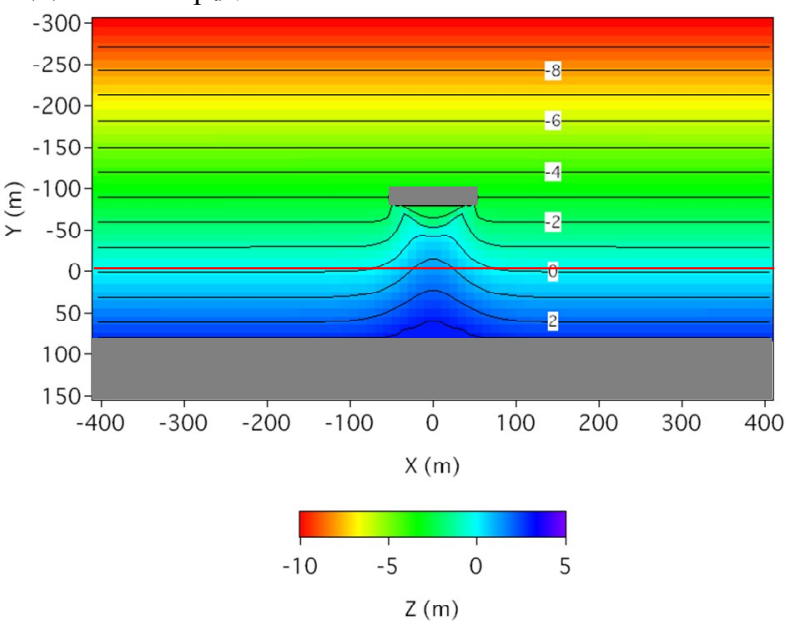

図-2 初期地形と計算結果（ケース1)

波高 $2 \mathrm{~m}$ 波を直角入射させた場合の波浪場を不規則 波の方向分散法により計算した。離岸堤は不透過性, その堤長は $100 \mathrm{~m}$ とし，海浜中央部の水深 $3 \mathrm{~m} に 1$ 基設 置した。この条件で $\Delta \mathrm{t}=0.1 \mathrm{~h}$ として $3 \times 10^{4}$ ステップ までの計算結果を図-2(b)に示す。図の赤線は初期 汀線を示す。これによれば, 離岸堤背後にはトンボ ロが形成されており，汀線の最大前進量は $40 \mathrm{~m}$ とな るので，この離岸堤では基準どおりの効果が得られ る。ただし, 汀線前進区域は, 離岸堤背後のX=-70m 〜 70mの $140 \mathrm{~m}$ 区間のみであり, 離岸堤による波の遮 蔽域外では汀線が後退しており, 最大後退量は $5 \mathrm{~m}$ と なる。このことから，基準に忠実に離岸堤を造る結

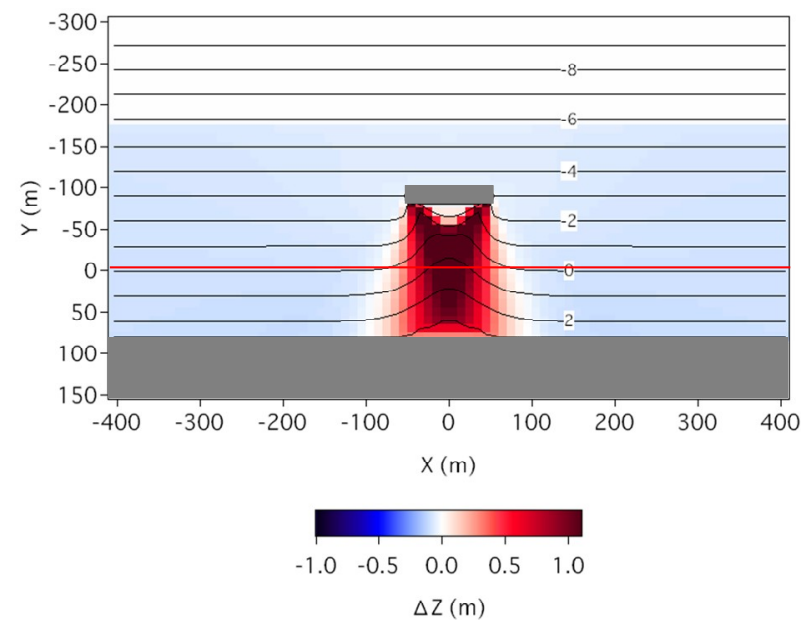

図-4 地盤変化量（ケース 1$)$ (a) 初期地形

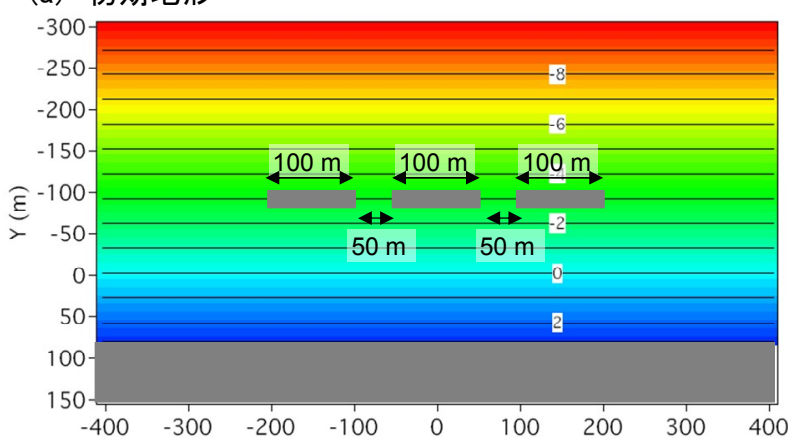

(b) $3 \times 10^{4}$ step後

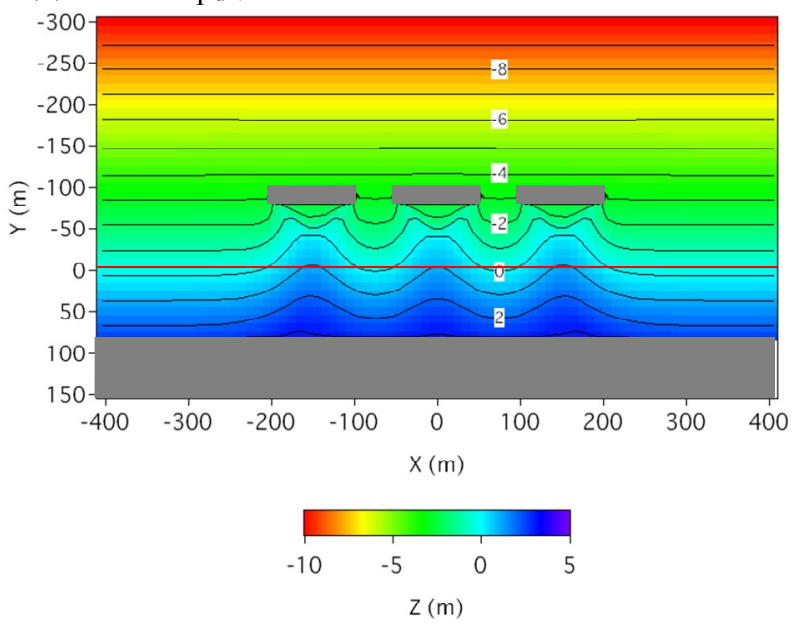

図-3 初期地形と計算結果（ケース2)

果として, 周辺域では離岸堤建設前よりも浜幅が狭 まり，越波が助長されかね㸚ない。しかしこのことに ついての記述がないので，事後に浜幅の減少が問題 となって浜幅が狭まった場所に再び離岸堤を設置す ることになる。そこでケース2では，図-3(a)に示す ように同じ規模の離岸堤を開口幅 $50 \mathrm{~m}$ で 3 基設置した。 当初設置の離岸堤の両端では汀線が後退するのみで なく局所的に波高が増大寸るのでその対応を基準に 従って行ったと考えたものである. $3 \times 10^{4}$ ステップ の計算結果を図-3(b) に示寸が，新設離岸堤の背後 にもトンボロが発達し, 汀線は離岸堤背後の長さ $316 \mathrm{~m}$ 区間で前進する。汀線の最大前進量は $38 \mathrm{~m}$ と

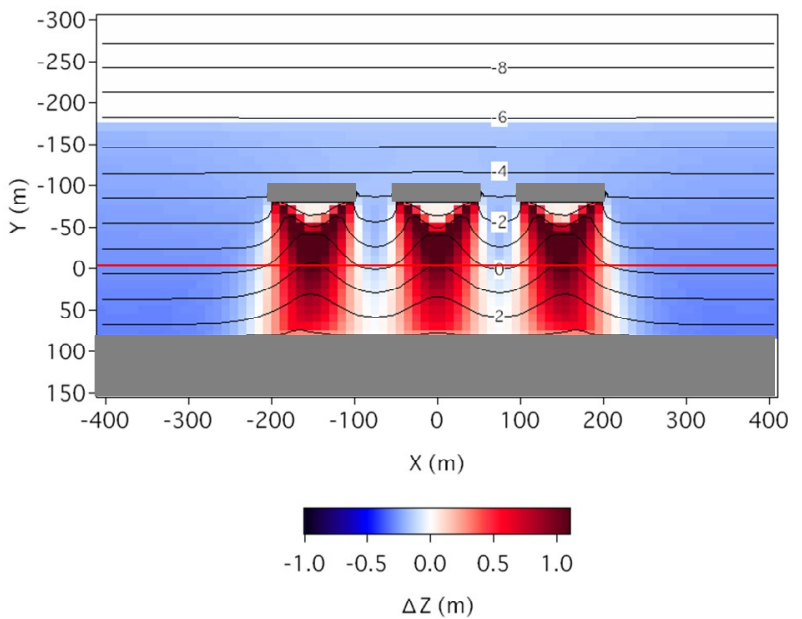

図-5 地盤変化量（ケース2） 
なって, ケース 1 とほほ同程度の汀線前進が得られ る. 3基の離岸堤の背後では開口部の一部を残して 前浜が広がることから, 離岸堤の設置効果が顕著と の評価となる。しかし離岸堤群の両側での最大汀線 後退量はケース 1 の 2 倍の $10 \mathrm{~m}$ なる。初期からの地 盤高変化量を算出したのが図-4（ケース1）である。 離岸堤背後の波の遮蔽域内では堆砂が進むが, 遮蔽 域外ではほぼ全域で侵食が進んでいる。侵食域での 平均地盤低下量は $0.08 \mathrm{~m}$ であり, 平均地盤上昇量は 1.04mであった。ケース2の同様な結果を図-5に示す.

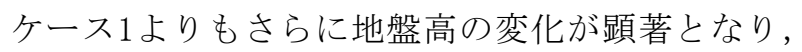
地盤低下量は $0.2 \mathrm{~m}$ となった.つまり比較的前浜の狭 い海岸で離岸堤を設置するとその隣接部の前浜が狭 まり，そこで対策を行うと連鎖反応的に設置域が広 がる。これを続けることは防護-環境-利用のバラン スを期待する海岸法の主旨と矛盾することは明らか である。

\section{5. 福岡県鐘崎海岸での海浜変形の事例}

近年, 離岸堤は異形ブロックが海面上に突出する ことから，景観や海岸環境が損なわれるとの認識が 広がり, 結果的に離岸堤に代わって人工リーフがし ばしば造られている. 人工リーフは離岸堤の代換施 設として位置付けられるがゆえに，4.で述べたとよ く似た地形変化が起こる，例えば，ポケットビーチ の一端に離岸堤や人工リーフなど波の遮蔽構造物が 造られると, 構造物背後の波の静穏域では堆砂が, その周辺部では侵食が起こる ${ }^{4)}$.この種の変形は防 波堤が伸ばされた場合にしばしば観察されるが，防 護施設としての離岸堤や人工リーフも規模は相違す るものの, 同種の地形変化が起こる. その典型的事 例には福岡県鐘崎海岸の例 $\left.{ }^{5}\right)$ があげられる。この海 岸は玄海灘に面し, 東（西）端を黒崎鼻（鐘ノ岬） により区切られた長さ約 $1.4 \mathrm{~km}$ のポケットビーチで ある。この海岸では，1984年より侵食対策として6 基の人工リーフ（天端幅 $50 \mathrm{~m} ，$ 天端水深 $2.2 \sim 3.2 \mathrm{~m}$ （H.W. L. 基準）が海岸東端部から建設された。

図-6 (a) は1961年の海岸状況を示すが，当時広い
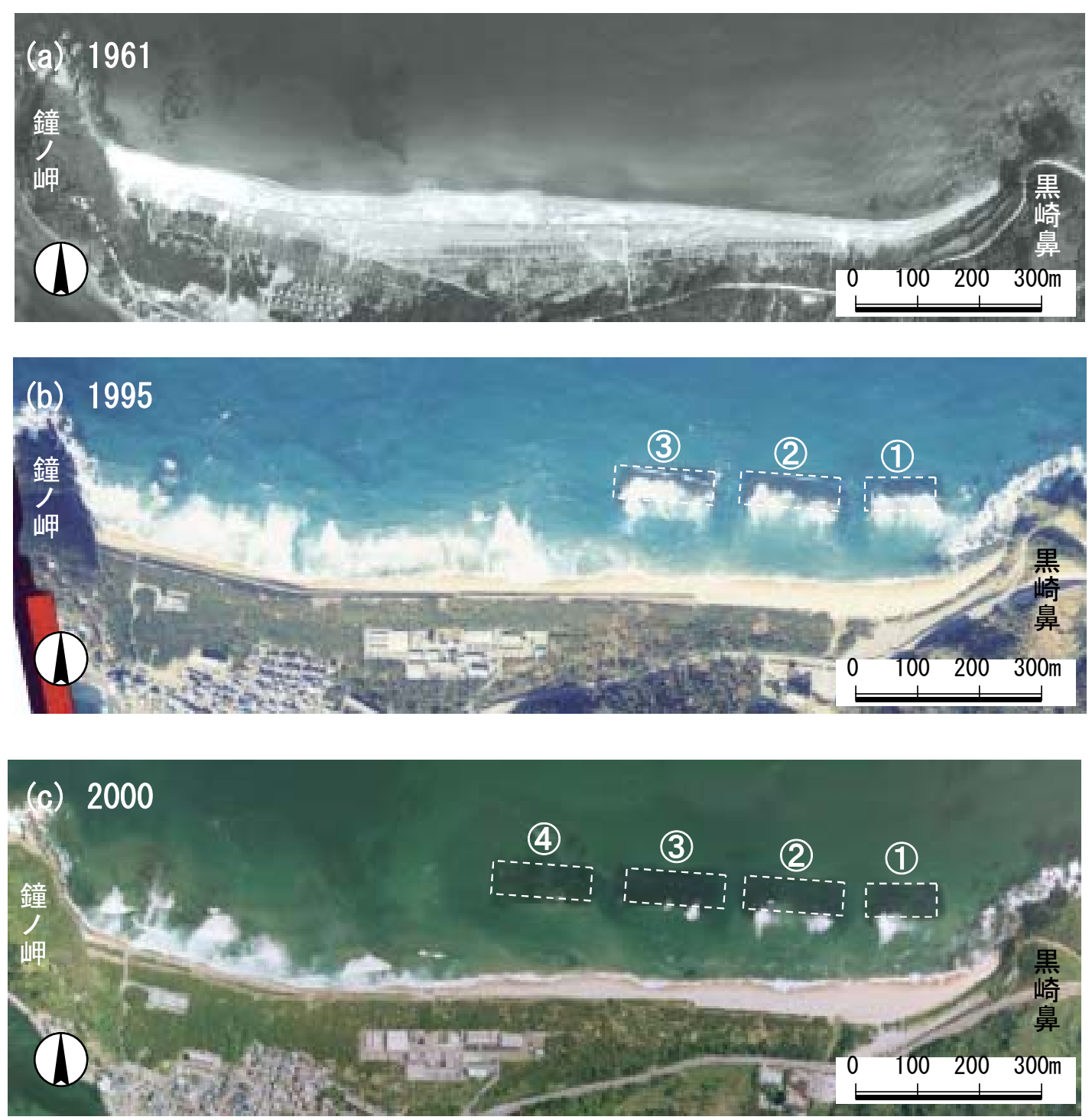

図-6 鐘崎海岸の空中写真 


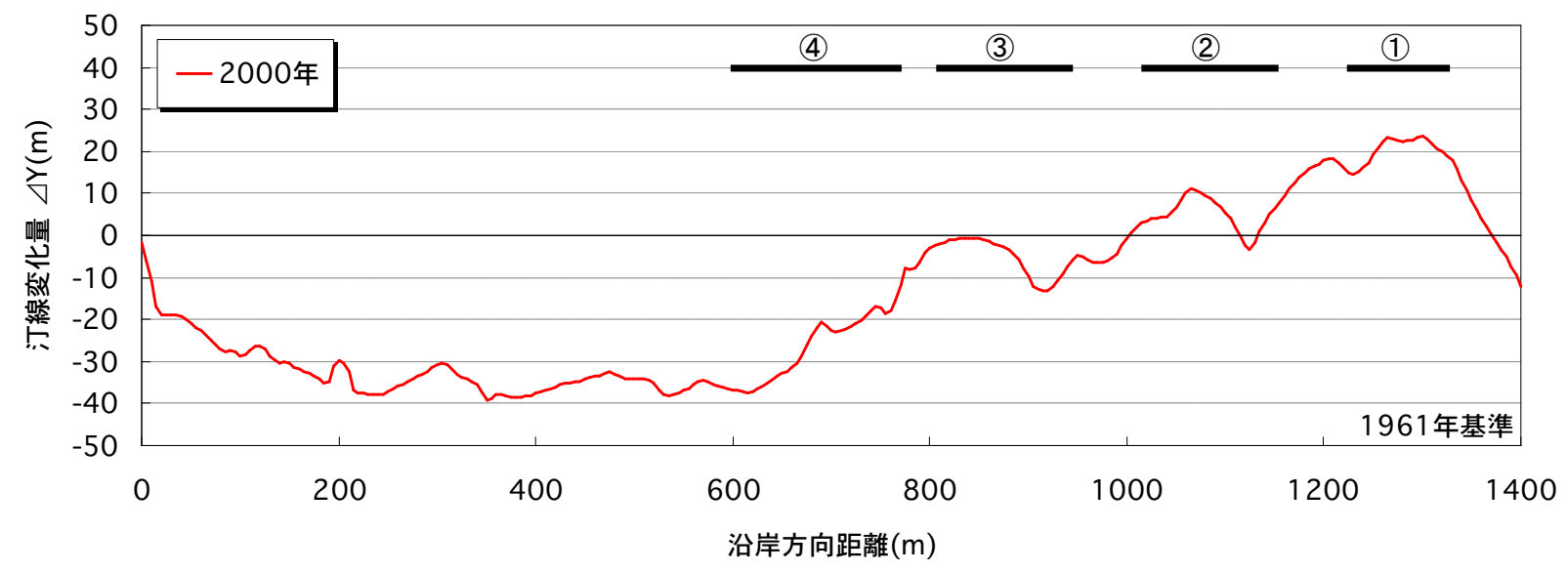

図-7 鐘崎海岸の汀線変化

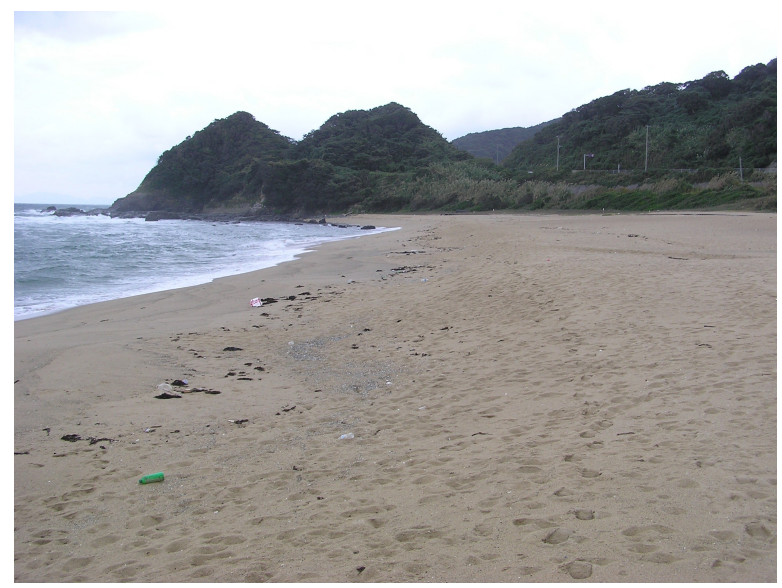

図-8 2号堤背後の海浜上において東端の黒崎鼻方面を 望む海浜状況

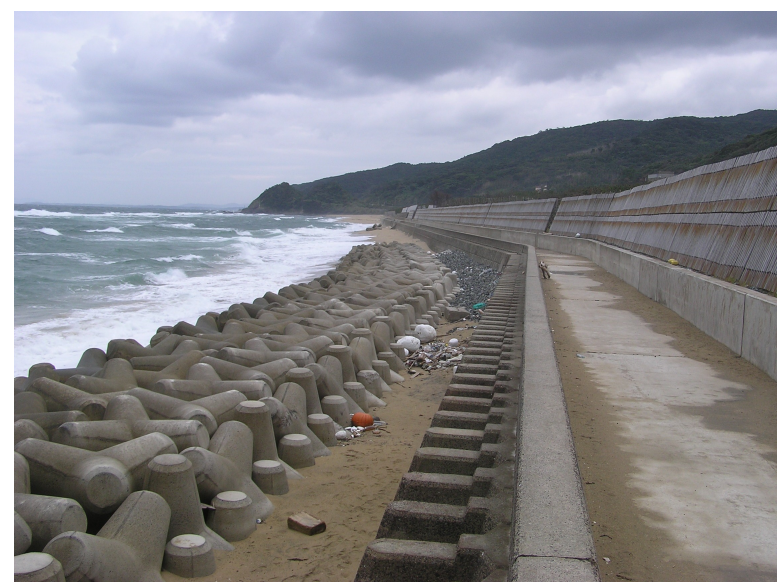

図-9 6号堤背後から海岸東部を望む

自然海浜が広がっていた。 人工リーフの建設開始か ら11年が経過し人工リーフ3基が完成した1995年に は，図-6(b)のように人工リーフの堆砂効果により その背後に砂が堆積し前浜が広がり始めた。これと 対照的に海岸西部では汀線の後退が起きた。ささに 図-6 (c) は，海岸中央部に新たに 4 号堤が造られた 2000年の海岸状況を示す.人工リーフ背後では堆砂 が進んだのと対照的に，西部の人工リーフ未設置区 間では前浜がほとんど消失した。これよりポケット

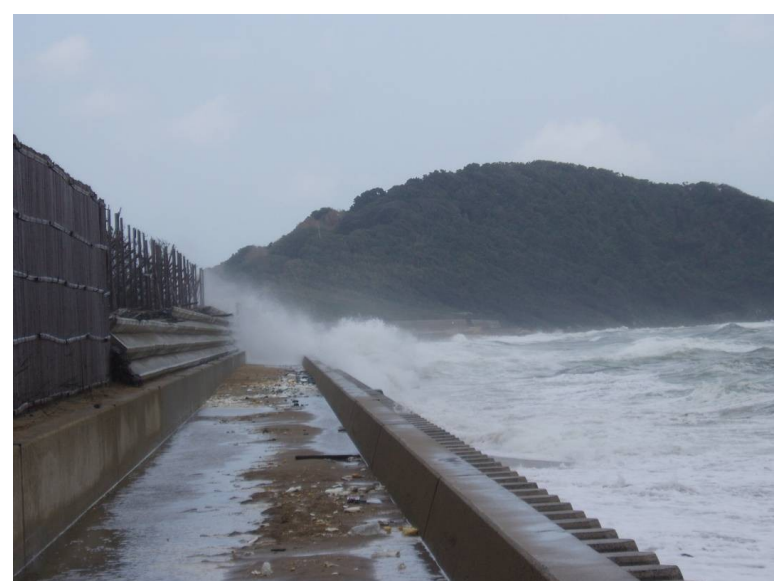

図-10 高波浪時の越波状況

ビーチの東端部から消波構造物が造られた結果，そ れらの消波構造物の背後へと西部から砂が運び込ま れたことが明らかである。図-7は1961年から2000年 までの汀線変化を示す. 2000年では1〜4 号堤の完 成後人工リーフ背後に舌状砂州が形成されたが，そ れに必要な土砂は海岸西部から沿岸漂砂によって運 び込まれたことが分かる.消波構造物背後での堆砂 と, その外側での侵食状況は図-3の計算結果と全く 同一である.

図-8は，2008年11月6日の現地踏査時に撮影した2 号堤背後の海浜状況であり，東端の黒崎鼻方面を望 んで撮影されている。この付近から東側には広い前 浜があることが明らかである。同様にしてほぼ6号 堤背後から海岸東部の状況を撮影したのが図-9であ る.開口部に当たるため波の作用が著しく, 直立消 波護岸前面の消波堤が波に曝されている。この付近 は完全な人工海岸に変わり高波浪時越波が激しい. 同じ場所の2006年10月6日の状況を図-10に示すが, 著しい越波が起きているのが分かる.

このように鐘崎海岸では，人工リーフの建設によ りポケットビーチ西部から東部への砂移動が起き, 西部では狭まった緩衝帯にあった護岸が直接波に曝 されることになった。この実例と4.の計算結果を考 
慮すれば，現在の「基準」の記述ではこのような現 実と大きな乘離があり，対策構造物の設置によって 新たな課題が発生し, それに対応していくうちに海 岸法の理念と大きくずれ，過剰に消波ブロックで覆 われた海岸になることが避けられない.4. で述べた ように構造物周辺の海浜変形予測が定量レベルで可 能なことから，あいまいな定性的基準から脱却する 時期に来ている，と筆者らは考える.

\section{6. 結論}

離岸堤設置によりその背後では堆砂が起こるもの の, 離岸堤周辺では侵食が顕著という状態はわが国 各地の海岸で見られる。この理由は, 離岸堤の設計 基準にこのような問題と, 問題への対処法の記述が ほとんどないことによると考えられる．問題の再発 を防ぎ，「基準」の冒頭で述べているように説明責 任を確保するには, 豊島が離岸堤を提案して以来多 くの実例が得られたことに加え, 現在では離岸堤周 辺の3次元海浜変形予測が可能となっているし, 離
岸堤建設時の汀線変化の簡易計算手法 ${ }^{5)}$ も示されて いることから，基準の中に周辺海岸への影響とその 定量的予測の必要性を記述すると同時に, その評価 を義務付けることが必要である。

\section{参考文献}

1) 海岸保全施設技術研究会編 : 海岸保全施設の技術上の 基準・同解説， 2004.

2) 芹沢真澄・宇多高明 - 三波俊郎・古池 鋼 : Bagnold 概念に基づく海浜変形モデル, 土木学会論文集 $\mathrm{B}$, Vo1. 62, No. 4, pp. 330-347, 2006.

3) 宇多高明：人為改変に起因するポケットビーチの汀線 変化，土木技術資料，Vol. 51-12, pp. 56-59, 2009.

4) 宇多高明：海岸侵食の実態と解決策, 山海堂, p. 304, 2004.

5）芹沢真澄・宇多高明 - 三波俊郎 - 古池 剛 - 神田康 嗣 : 修正 HSU モデルによるへッドランド周辺の最適安 定海浜形状の計算法, 海岸工学論文集, 第 43 巻, pp. 646-650, 1996. 